\title{
ФЕНОМЕН ЭКОНОМИЗМА
}

\begin{abstract}
Аннотация. Статья вводит как противоположные понятия экономики и и экономизма. Раскрывается взаимоотношение экономизма с механицизмом; анализируется способ существования человека и общества, места в ней экономики, возникновение феномена экономизма; исследуется экономика, ее цели и способ существования, противоположностью которой, согласно автору, выступает описываемый им феномен экономизма. Раскрывается неадекватность механицизма и экономизма философской онтологии (диалектике бытия) и динамике науки, бытию классической, неклассической и постнеклассической науки. Показано, что экономизм выступает основанием отчуждения человека от социальности. В этом он идентичен механицизму, отчуждавшему человека от материальности. Основным методом является диалектика, конкретизируемая совокупностью методов: объективности, противоречивости диалектики позитивной и негативной, исторического и логического, восхождение от абстрактного к конкретному, компаративистского исследования. В статье дан анализ философских оснований экономики, выявлен феномен экономизма, раскрыто его влияние на экономику, общество и его сферы. Дан сравнительный анализ экономизма и механицизма, их неадекватность бытию и его развитию, философской картине мира. Механицизм есть подмена философской онтологии естественнонаучными представлениями (в духе позитивизма), экономизм подменяет социальную онтологию понятиями гуманитарных наук. Их преодоление обосновывается также методом раскрытия эволюции науки, изменением ее объективного содержания (наука классическая, неклассическая и постнеклассическая), противоречащего механицизму и экономизму. Показано, что феномен экономизма является основанием отчуждения человека от социальной реальности - как механицизм является основой отчуждения от материальной реальности.
\end{abstract}

Ключевъе слова: общество, сфера, развитие, экономизм, механицизм, часть, целое, эволюция, философия, наука.

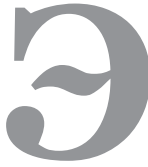

кономика является одной из сфер общественной жизни, которая создает условия для существования и развития человека и общества, всех его сфер. Она не может заменять собой другие сферы общества и человеческой деятельности, «проглатывая» или подминая их. По Т. Парсонсу, общество состоит из трех подсистем: культуры из ценностей, норм и образцов, регулирующих действия и поступки людей, экономики, основная функция которой есть адаптация к внешней среде, и социальнополитической подсистемы с функцией интеграции общества; в их взаимодействии порождается консумматорное состояние удовлетворения. Достигается оно благодаря «кодам социальной информации и управлению, учитывающему обратное влияние результатов деятельности на целостное состояние социальной системы» .

${ }^{1}$ Стёпин В.С. Цивилизация и культура. СПб., 2011. С. 175.
Такой подход оставляет нас в границах саморегулирующихся систем.

Переход к более сложным саморазвивающимся «человекоразмерным» системам дополняется идеей изменения видов системной целостности, сопровождающей развитие системы, учитывает «переход от одного типа саморегуляции к другому», вводит представления «о превращении возможности в действительность», «целевой причинности» и направленности развития в «эволюции основных сфер Универсума неживой природы, живой природы и общества», охватывающей все уровни организации материи ${ }^{2}$. Эта более сложная «картина мира» выступает ядром «исследовательской программы по отношению к эмпирическим и теоретическим исследованиям конкретных наук»³, она распростра-

\footnotetext{
${ }^{2}$ Там же. С. 179-181.

${ }^{3}$ Там же. С. 182.
} 


\section{Философия и культура 1(73) • 2014}

няется и на экономику. Напротив, утверждение, что «экономическая деятельность не просто отличается от всех других проявлений общественной жизни, но, сверх того, обусловливает общество в целом, а порой и господствует над ним» ${ }^{1}$ лежит в русле не экономики, но экономизма, который все еще встроен в механизмы, посредством которых мы производим и воспроизводим свою материальную жизнь. Различие экономики и экономизма нам и предстоит показать.

Сущностной характеристикой человека выступают его потенциальная универсальность, бесконечность и всеобщность, реализуемые «производстве», в акте преобразования окружающей реальности, которое есть также «полная разработка потенциальных возможностей человека», «развитие всех человеческих способностей как самоцель», развитие «без всякой установленной заранее мерки»². Это предполагает «соразмерность» человека всему бытию, способом существования которого является развитие - единство прогресса и регресса, в котором доминирует тенденция поступательного восхождения. Именно этот способ существования мира приводит к появлению человека, в котором и через которого продолжается мировое изменение. Примечательно, что «в работах Маркса к понятию «производство» относится любая обеспечивающая самореализацию деятельность, будь то игра на флейте, угощение персиками, спор о Платоне, быстрый танец, произнесение речи или организация празднования для рождения детей <...> Когда Маркс говорит о сущности производства как сущности человечества, он не имеет в виду, что сущность человечества состоит в набивании колбасы. Труд, как мы знаем, есть отчужденная форма того, что он называл praxis - слово, означавшее у античных греков вид свободной, самоорганизуемой деятельности, посредством которой мы преобразуем мир»3. В бытийном «контексте» экономика призвана создавать условия восходящего развития человека и человечества, выполняя в обществе и его развитии соответствующие функции. Однако в каждый период человек ограничен совокупностью конкретных, локальных и исторических условий - природных и общественных, включая экономические. Но место и роль человека зада-

\footnotetext{
${ }^{1}$ Иглтон Терри. Почему Маркс был прав. М., 2013. С. 147.

2 Там же. С. 167.

${ }^{3}$ Там же. С. 167-168.
}

ется его родовой сущностной универсальностью, всеобщностью и бесконечностью, благодаря чему бытие сохраняет и продолжает свое восхождение, имея в нем свое «продолжение». Развитие жизнедеятельности человека как общественного существа и прогресс культуры, наследующий природное восхождение к разуму и продолжающий его в направлении все большей «человечности» связан с разрешением указанного противоречия. В совокупность ограничений вносит вклад и экономика, в то же время ее существование и развитие связано и с позитивной диалектикой бытия, с преодолением всевозможных границ и ограниченностей. Иначе она стала бы принципиальным препятствием для развития бытия, общества, человека и человечества. Значит, критерий прогрессивного развития, его доминирования над проявлениями негативной диалектики задается дополнением бытийных характеристик характеристиками диалектики развития.

От этого критерия, которым следует поверять экономику и ее динамику, отказались «реформаторы» в постсоветской России, заявив знаменитое: «Мы не можем выбирать между плохим и хорошим, мы вынуждены выбирать между плохим и еще более плохим». Это предопределило курс «на выживание», а не на развитие страны, общества и каждого человека как важнейшего субъекта (цели в себе, по И. Канту) и ресурса развития страны и общества. Ими стали пренебрегать, поставив на первый план интересы олигархов, к которым добавились чиновники, особенно при выстраивании «вертикали власти». Не случайно, в работе Е. Гайдара «Государство и эволюция» (М., 1994) субъектами истории признаются только бизнесмены и чиновники, которые ведут между собой борьбу по типу «господство и/или подчинение», тогда как третья категория людей признаются скорее «средствами производства», орудиями труда. Эта «страдательная категория» не признается субъектом истории, вследствие «экономизма». Переход, условно говоря, «от Ельцина к Путину» не отменил этой идеологии, но явился существенным изменением: стала выстраиваться «вертикаль власти», укрепляться позиции чиновников государства, тогда как Е. Гайдар мечтал «освободить бизнес от власти» (сказано в подзаголовке книги), превратить государство в «полугосударство», чтобы всеми процессами в обществе «заведовала» знаменитая рука Адама Смита, чтобы все было «погружено» в рынок, чтобы рыночной была не только эконо- 


\section{Социальная динамика}

мика, но и общество, превращаемое в общество потребления. Это означало, что общество, частью которого является экономика, и так понятая экономика меняют местами, общество и все его сферы «погружаются» в рынок как то целое, «логос» которого явно абсолютизируется в виде руки Адама Смита. «Экономизм» предполагает наличие социального неравенства между богатыми и бедными, «средствами производства».

При всех «революционных» изменениях перехода «от Ельцина к Путину» прочие слои населения так и остались "орудиями труда», «средствами производства», актуальными или потенциальными (= безработные). Выстраивание «вертикали власти» привело к возрождению государства ${ }^{1}$, возобновившего ненавистное стремящимся быть субъектами людям крайнее социально-экономическое неравенство, классовое общество, появившееся в годы гайдаровской «при (х) ватизации» и продолжающееся доныне - вследствие сохраняющего свои позиции и «при Путине» «экономизма», где труд одних повышает чужую для них прибыль и могущество «имущих» и «властвующих». «Экономизм» вышел за рамки влиянии на экономику, воздействуя на все общество в целом и его части или сферы. Противоречия, раздирающие современную Россию, подталкивают к тому, чтобы сформулировать следующий острый вопрос: нуждаются ли страна и ее жители в том, чтобы ученые «выдвигали и обосновывали варианты, сценарии, альтернативы, перспективы будущего прорывного, прогрессивного, социально справедливого развития российского общества, российской цивилизации, русского народа, человека» или достаточно, чтобы они «просто успокаивали их, призывала их быть терпимыми, примиряться с несправедливой, дикой реальностью, полагались на действия «свыше» - от власти, от политических и духовных правителей и пастырей?»².

Это - вопрос о приоритетах. Ведь человек есть высшее существо для экономики, именно на эту высоту надлежит поднять общество и экономику, увидев в человеке цель, а не простое средство для эволюции всепоглощающей собой экономики. Формы же, которые принял процесс «реформ» в России, как и состояние экономики,

${ }^{1}$ См.: Алексеев П. В., Панин А.В. Философия. М., 2014. С. 384.

${ }^{2}$ Семенов В.С. Судьбы философии в современной России. M., 2011. C. 17. подорванное воздействием усилившего свои позиции экономизма, привел к разрушительным последствиям - вследствие кризиса властных и духовных «элит» «тупика» ${ }^{3}$, «растления. Растления на всех уровнях и во всех сферах» ${ }^{4}$.

России нужна сборка субъектов прогрессивного развития, в контекст которого должна быть «помещена», для своего развития, и экономика. Экономизм же является антиподом такому развитию страны, как он является тормозом и для экономики, извращающим ее началом.

Чтобы раскрыть сущность экономизма и последствия его влияния на экономику и общество, без уяснения чего невозможно его преодоление, сравним, сопоставим его с механицизмом, который давно обнаружил свою несоразмерность с бытием и его развитием. Механицизм есть мировоззрение (миропонимание), основанное на представлении, будто механическая форма движения есть единственная и последняя объективная и наиболее фундаментальная реальность, в пределах (на основе) которой существует и может быть объяснено всякое существующее сущее. Он «переносит» в механические представления понятия физики, химии и биологии, лишая соответствующие явления их специфики, которая явно выходит за границы механики; так же механицизм обращается с философскими категориями (причинности, взаимосвязи и т.д.), будучи не в состоянии учесть реальной диалектической сложности движения и развития материального мира и его явлений. В этом состояла «абсолютизация» законов механики, в сферу действия которых погружали все виды материального движения. Его последовательное проведение приводит к отрицанию качественного многообразия явлений в природе и обществе, к представлению, что многообразие есть лишь субъективная иллюзия, что сложные явления правомерно «сводить», редуцировать к более простым составляющим.

Характеризуя механицизм, нередко выделяют «исторические формы механицизма» ${ }^{5}$, демонстрирующие различные его аспекты. Первый связан с рассмотрением движения как внешнего по отношению к неизменяющейся субстанции,

\footnotetext{
${ }^{3}$ Напр.: Козин Н.Г. Есть ли будущее у России? Критика исторического опыта современности. М., 2008.

${ }^{4}$ Максимов В.Е Самоистребление. М., 1995. С. 3.

5 Петушкова Е.В. Механицизм//Новейший философский словарь. Минск, 1998. С. 421.
} 


\section{Философия и культура 1(73) • 2014}

носителю движения. Здесь логически равноправны утверждения, что объекты могут находиться, а могут и не находиться в движении. А ведь движение есть способ, каким существует бытие.

Бытие - базовое понятие философии. Его формирование было связано с постановкой и решением основного вопроса, разделившего философское познание на альтернативные направления материализма и идеализма. К определению бытия, адекватному такому размежеванию философия пришла не сразу. Определение бытия как материи, то есть определение бытия в соответствии с разделением на материалистов и идеалистов, было дано В.И. Лениным, оно стало классическим. Прежде оно сдерживалось путаницей, механистической интерпретацией бытия, затрудняя введение обобщающих понятий «материалисты» и «материализм», антитетичных по отношению к понятиям «идеалисты» и «идеализм», важных "для понимания сути главных философских конфронтаций»⒈ Так, С. Кларк (1675-1729) находил «материалистическим» "космогонически-механический натурализм», писал, что согласно «материалистам строение Универсума возникло исключительно из механических начал материи и движения» в противоположность «Математическим началам натуральной философии» И. Ньютона, который так и не смог построить удовлетворительной модели для действия тяготения и распространения электромагнитных волн в рамках механицизма и обосновывал положение, что «строение Солнца и планет может возникнуть только по разумной и свободной Причине»². Дж. Локк, руководствуясь взглядами механицизма, утверждал, что от Бога исходит движение тел, что сама материя есть продукт божественного творения (это мнение сохранилось до сих пор 3 ).

В Новое время развитие и обоснование механицизма обнаруживает связь с расчленением знаний о субстанции (материи) и движении в различных областях науки. Допускалось существование особых видов фантазийной «невесомой» материи (теплорода, светорода, электрических

\footnotetext{
${ }^{1}$ Кузнецов В.Н. Проблема значения понятий «материалисты» и «материализм» в новоевропейской философии XVII-XVIII веков» // Историко-философский альманах. Вып. 2. М., 2007. С. 55.

2 Лейбниц Г. В. Сочинения: В 4-х т. Т. 1. М., 1982. С. 432, 437.

${ }^{3}$ Напр.: Моррис Генри. Сотворение мира: научный подход. Сан-Диего, Калифорния, 1981.
}

и магнитных флюидов) 4 и столь же воображаемых природных сил-симулякров, соединения их с изучаемыми изменениями тел («плавательная сила», «магнитная сила» и т.д.). Эта форма механицизма в науке и философии была преодолена, когда было раскрыто, что многообразные природные силы и формы энергии суть проявления одного и того же единого сохраняющегося движения, суть его различных видов (закон сохранения и превращения энергии).

Вторая историческая форма механицизма связывается с употреблением понятия движения только в «зауженном» смысле пространственного перемещения тел (механическое движение), приводя к неадекватности механистических представлений миру в его бесконечности, универсальности, неисчерпаемости. Даже когда в философии были выдвинуты утверждения о движении как атрибуте и способе существования материи (Толанд, Гольбах, Дидро), то, строго говоря, имелось в виду простое механическое перемещение, а не движение как изменение и взаимодействие «вообще», во всем богатстве его неисчерпаемых проявлений.

Третья историческая форма механицизма связана с крайностями применения метода редукции более сложных форм движения к более простым, когда игнорируется многоуровневость внутренне противоречивой природы движения и качественное своеобразие законов каждого уровня, не сводимое к законам других уровней движения. Для механицизма в целом как мировоззренческой установки характерно сведение сложного к простому, целого к сумме частей, отрицание качественно своеобразных законов у объектов с различным типом системной организации. Он порожден тем, что механика была в свое время единственной наукой, получившей достаточное развитие и применение в производстве, казалась «наукой вообще». Это препятствовало формированию философских представлений о бытии как движущейся материи, приводя к путанице философии и конкретной науки (в духе позитивизма): «часть», одна из форм движения материи представала в качестве того целого, в котором «расплавлялось» все сущее; она подменяла собой «материю». Любая сколь угодно сложная и развитая форма движения материи заключает в себе механическое движение,

\footnotetext{
${ }^{4}$ Философы-постмодернисты говорят в таких случаях о «симулякрах».
} 
к которой и происходит ее «редукция». Это ведет к утверждению принципиальной невозможности познания ее качественной специфики, знание, которое раскрывало бы «надмеханическое содержание», объявляется ненаучным, оно ведет к третированию диалектических понятий и категорий, вместо которых механицизм конструирует некие внешние силы, в которых реальные моменты, абстрагированные от движения, превращаются в самостоятельно существующие, будто бы субстанциальные механические «причины» этого движения, в особые «силы».

Механицизм принято рассматривать как проявление неспособности «сладить» с противоречиями, играющими в диалектике принципиальное значение источников движения и развития. Неслучайно, в эпоху засилья механицизма были распространены представления, что материя лишена активности, что источником движения и развития выступает Бог, духовное первоначало, обладающее бесконечной Силой и высшим Умом, от которого происходят все низшие сущие. Этот вопрос стал ключевым в истории XVI-XVIII веков ${ }^{1}$, демонстрируя путаницу философского «материализма» и «механицизма» (впрочем, проявления механицизма были присущи и философам-идеалистам), проистекающей из гипостазирования механики как науки, в которое уже явно не вмещалась «антропо-социальная философия» мыслителей, стремившихся к усовершенствованию человеческого общества в соответствии с чаяниями тех людей, которые, как писал, например, П.А. Гольбах, «берутся за оружие, чтобы, рискуя жизнью, положить конец своим страданиям»².

Как пишет В.Н. Кузнецов, «антропо-социальная философия Гольбаха примыкала к его материалистической «философии природы», но по существу не была (вопреки видимости и утверждениям самого автора) ее логически необходимым следствием»3. Она должна была

\footnotetext{
${ }^{1}$ Кузнецов В.Н. Проблема значения понятий «материалисты» и «материализм» в новоевропейской философии XVII-XVIII веков» // Историко-философский альманах. Вып. 2. М., 2007.

${ }^{2}$ Гольбах П.А. Избранные произведения: В 2-х т. Т. 1. М., 1963. С. 341.

${ }^{3}$ Кузнецов В.Н. Проблема значения понятий «материалисты» и «материализм» в новоевропейской философии XVII-XVIII веков» // Историко-философский альманах. Вып. 2. М., 2007. С. 76.
}

исходить из более универсальной, философской, а не научной категории, через которую определяется бытие. На основе обобщения данных всех наук философский материализм интерпретирует механическое движение как сторону, «абстрактно-всеобщее условие всякого движения. В составе высших, надмеханических процессов оно оказывается «побочной формой», необходимой, но далеко недостаточной для характеристики природы этих процессов»4.

Преодоление механицизма в целом происходило в XX в. Сегодня место механицизма занимает экономизм. Такая замена соответствует духу перехода «от позитивизма к постмодернизму», делающего ставку на гипостазирование понятий и явлений гуманитарных, а не естественных наук. В самом общем виде экономизм характеризуется тем, что все многообразие явлений, прежде всего связанных с человеком и его существованием, «погружается» внутрь экономики, как если бы экономика была не стороной, частью общества, всей общественной жизни, но самим этим «универсумом» общественной жизни, который она подменяет и «подминает» под себя - как в механицизме механическая форма движения претендовала на подмену всех иных, более сложных форм движения материи; «подминала» их под себя. Например, сегодня в России в экономику погружены, грубо «засунуты» сферы образования (в качестве сферы услуг), науки (абсолютизируют прикладную и недооценивают фундаментальную), искусства, медицины, управления, физической культуры и другие, как если бы они были не частями общества, всей общественной жизни, к которым относится и экономика, но частями экономики, пораженной экономизмом.

На явление экономизма обратил внимание уже К. Маркс, который выдвинул проект его преодоления 5 , аналогичный преодолению механицизма, но уже в сфере «философии истории» («Экономическо-философские рукописях 1844 г.», «Тезисы о Фейербахе», 1845 г.). «Общество экономики» уже было тогда описано классиками «политической экономии». Они показали «пещерное бытие» человека в мире экономики, которая, будучи частью общества,

\footnotetext{
${ }^{4}$ Потемкин А. Механицизм // Философская энциклопедия: В 5-и т. Т. 3. М., 1964. С. 425.

${ }^{5}$ Прохоров М.М. Несколько соображений о марксистской философии и современности // Вестник Российского философского общества. 2010. № 4 (56). С. 87-91.
} 


\section{Философия и культура 1(73) • 2014}

подчинила своей власти его как целое. Против этого состояния и было направлено материалистическое понимание истории К. Маркса, который был уверен, что экономика есть необходимое условие жизни, ибо без экономического базиса невозможна жизнь человека, как уверен он был и в том, что цель и смысл человеческой жизни лежит совсем не в этом необходимом базисе жизни, что можно и нужно поставить его на место части общества, чтобы она не подчиняла себе жизнь общества в целом. Именно в этом пункте Маркс расходился с «политико-экономами», позитивно относившимся к господству части над целым. В разделе «Заработная плата», не потерявшем своей актуальности и сегодня, Маркс показывает, что она, во-первых, определяется враждебной борьбой между капиталистом и рабочим, а указывая на причины поражения в этой войне тех, кто вынужден продавать свой труд, и когда богатство общества прогрессирует, и в кризисные времена, когда оно «приходит в упадок», что, во-вторых, «согласно политико-экономам, интерес рабочего никогда не противостоит интересу общества, тогда как в действительности общество всегда и непременно противостоит интересу рабочего», ибо своим «гнетом вообще он обязан этому строю общества»; напротив, «интерес капиталистов $<. . .>$ враждебно противостоит интересу общества», что может быть лишь смягчено, но не отменено «конкуренцией капиталистов»1.

Того, кто живет только своим трудом, классики политической экономии даже не рассматривают как человека, различая - Маркс цитирует работу В. Шульца «Движение производства. Историко-статистическое исследование для обоснования новой науки о государстве и обществе» ${ }^{2}-$ «между работой человека с помощью машины и его работой в качестве машины». Они - цитирует К. Маркс первый том работы Э. Бюре «О нищете рабочих классов в Англии и во Франции» $3,-$ «не люди, а лишь орудия производства». На с. 74 Э. Бюре добавляет, что «в будущей жизни народов действующие в машинах

\footnotetext{
${ }^{1}$ Маркс К. Экономическо-философские рукописи 1844 г. // Маркс К., Энгельс Ф. Из ранних работ. М., 1956. С. 528-529, 538.

2 Шульц В. Движение производства. Историкостатистическое исследование для обоснования новой науки о государстве и обществе. Цюрих, 1843. С. 69.

${ }^{3}$ Бюре Э. О нищете рабочих классов в Англии и во Франции. Париж, 1840. С. 68-69.
}

слепые силы природы станут нашими рабами и крепостными» ${ }^{4}$. А пока что хозяин, покупающий труд рабочего по цене столь низкой, что ее едва хватает рабочему для удовлетворения наиболее настоятельных потребностей, «не виновен» ни в недостаточности заработной платы, ни в чрезмерной продолжительности работы, ибо он сам повинуется «силе вещей».

Н.А. Бердяев также указывал, что человечество все еще живет в «экономическом веке» ${ }^{\text {, }}$ что в экономике люди видят не столько сферу средств, сколько идентифицируют ее с целью, смыслом человеческой жизни, погружая все в экономику. И возражает: экономика (как и техника) «всегда есть средство, а не цель», не может быть технической или экономической цели жизни, «цели жизни всегда лежат в другой области», хотя часто средства жизни подменяют цели жизни, а в нашу эпоху - в особенно крупных масштабах. Н.А. Бердяев поясняет, на примере техники, что она для ученого или изобретателя, непосредственного занятого именно в этой сфеpe, конечно, может стать главным содержанием жизни, но не больше. Но и в этом случае нельзя оставаться в границах «экономизма», соответствующего ему видоизменения экономики. Ведь человек есть существо универсальное, соразмерное бытию и его развитию, появившееся на уровне социума.

Возникший на рубеже XX-XXI веков экономизм в социал-демократии критиковал В.И. Ленин. Он видел его сущность в редуцировании действий трудящегося до стихийного процесса, поглощенности экономизмом: «рабочим - экономическая, либералам - политическая борьба» (звучит вполне современно - М.П.). Речь шла о борьбе против зауженных в духе

\footnotetext{
4 Это - уход человека из сферы производства в смысле отчужденного труда. Она переходит к техническим средствам, наделенным, как мы теперь знаем, искусственным разумом и реализующим функции создания потребных для людей благ, которые прежде создавались при непосредственном участии человека. Теперь человек становится «рядом»с таким производством, осуществляемым с участием IT-техники. Таково качественное изменение, совпадающее, согласно С. Платонову, с переходом к коммунизму (Платонов С. После коммунизма: Кн., не предназначенная для печати. 2-ое изд.; Второе пришествие: Беседы. М., 1991).

${ }^{5}$ Бердяев Н. А. Человек и машина. Проблема социологии и метафизики техники // Вопросы философии. 1989. № 2. C. 148.

${ }^{6}$ Ленин В. И. Полн. собр. соч. 5-е изд. Т. 26. С. 343-344.
} 


\section{Социальная динамика}

экономизма «экономических задач борьбы», хотя классы не есть чисто экономическое явление.

Вообще «трудно представить себе такое нечто, которое было бы чисто экономическим. Даже монеты», ибо их «можно собирать и выставлять как экспонаты в витринах, восхищаясь их эстетическими качествами», хотя они позволяют «понять, почему все человеческое бытие так легко свести к экономике»: «наиболее чудесным и загадочным в деньгах является то, что они, как мощнейший аккумулятор, сосредотачивают» «почти безграничное богатство человеческих возможностей», «обеспечивают нам доступ к большинству из них», «позволяют нам налаживать полноценные отношения с другими людьми без опасения сконфузить окружающих, в самый неподходящий момент упав и скончавшись от голода у них на глазах», «вызывать поразительные перевоплощения товаров из их исходной, ничем не примечательной формы. Денъги сами по себе есть форма редукционизма. В пригоршне медяков заключены целые вселенные» (выделено мной - М.П.) ${ }^{1}$.

Экономизм преодолевается ради утверждения социальности человека как универсального существа, порожденного развитием бытия, приведшего к выделению социума, общества из природы и продолжающего в этой новой форме бытия материи ее развитие, в котором восхождение побеждает нисхождение, деградацию, вырождение. Сфера экономики призвана создавать для этого необходимые условия, обеспечивая человеческие потребности людей. Но ее следует освободить от экономизма, тех же «политико-экономов», которые, подобно энтомологам, изучающим каких-либо букашек, позитивно относятся к обществу, в котором господствует «частный интерес», это «несчастье общества», феномен экономизма. Они позиционируют себя просто как ученых, которые, вспомним Э. Бюре, изучают и описывают то, как «промышленность стала войной, а торговля - игрой», констатируют что «положение рабочего перед лицом того, кто использует его труд, не есть положение свободного продавца», ибо «капиталист всегда волен использовать труд, рабочий же всегда вынужден его продавать», что «для того, чтобы жизнь человека была товаром, надо допустить рабство», что до сих пор промышленность находилась в состоянии завоевательной войны: «она расточала жизнь людей, образующих ее армию,

${ }^{1}$ Иглтон Терри. Почему Маркс был прав. М., 2013. С. 163-164. столь же хладнокровно, как и великие завоеватели. Целью ее было обладание богатством, а не счастье людей». «Полит-экономов» можно сравнить и с историками, изучают прошлое, когда существовали рабы: мы же не можем, скажут они, «бывшее сделать небывшим», а просто изучаем «то, что было» и научным способом его воспроизводим, описываем. Вот такой позитивизм и есть презумпция «экономизма».

Иной позиции придерживается К. Маркс ${ }^{2}$, давая философское обоснование экономической науке. Для него философия есть, прежде всего, своего рода «зеркало» диалектики процесса развития, некоторый способ самосознания «восходящего класса». Философ приводит все познания в единство, руководствуясь определенными направляющими схемами анализа и обобщения, которые повергают на суд эпохи и мира образ действий и методы, применяемые восходящим классом. Философия, пребывающая в полной силе, никогда не выступает как нечто инертное, как пассивное и уже завершенное единство знания. Будучи порождаема общественным движением, она представляет собой это движение бытия и простирает свое влияние на будущее. Ее конкретное обобщение перерастает в проект будущего развития, проект изменения мира. В этом плане философия характеризуется как метод исследования и объяснения; ее вера в себя и в свое будущее развитие лишь воспроизводит убеждение класса, который служит ее носителем. Следовательно, любая философия является практической, даже та, что поначалу кажется сугубо «созерцательной», ибо ее «метод» есть «социальное и политическое оружие».

К. Маркс указывает и на другой полюс, мышление представителей которого определяется

\footnotetext{
${ }^{2}$ И сегодня «экономика никогда не предстает в виде принадлежащих только ей предметов. То, что финансовая пресса называет экономикой, есть род фантома. Определенно можно сказать, что ее никто и никогда не видел. Это есть абстракция сложного общественного производства. И как раз ортодоксальная экономическая мысль склонна сужать понятие экономики. Напротив, марксизм исходит из более развернутой и содержательной трактовки производства. ... Он утверждал, что большинство совершающихся производств вообще не является подлинным производством. По его мнению, люди только тогда по-настоящему производят, когда они это делают свободно и ради самих себя. В полной мере это станет возможным только при коммунизме». Маркс считал «искусство» примером «неотчужденного труда» (Иглтон Терри. Почему Маркс был прав. М., 2013. С. 164-165).
} 


\section{Философия и культура 1(73) • 2014}

попытками найти прибежище от объективности в утонченной субъективности, чтобы не видеть своего будущего, которое определяется вырождением, уходит в небытие. Он исследует историческую преходящность пещерных условий экономизма, возможность перехода в «царство свободы», которое «начинается там, где прекращается работа, диктуемая нуждой и внешней целесообразностью, следовательно, по природе вещей оно лежит по ту сторону сферы собственно материального производства» ${ }^{1}$, хотя и не по ту сторону процесса развития бытия, мира в целом (как учит «верить» религия). Первое относительно, преходяще, второе абсолютно, непреходяще. Когда же преходящность мира гнета и нужды, господство экономики (и техники) реализует себя, только тогда марксизм исторически и логически изживет себя, станет историей. К. Маркс ищет пути восстановить социальность, поставив развитие экономики под контроль людей, общества, чтобы не жить в «пещере» экономизма как в тюремном заключении и не глядеть на все через денежные знаки (сегодня - рубля, доллара или евро), но ценить все сущее по его собственным характеристикам и критериям. Следовательно, марксизм не утверждает материальность как вечное господство экономики, пораженной и сраженной экономизмом, как это нередко утверждается. Напротив, он открывает преходящность сражаемой экономизмом экономики. Марксизм есть не утверждение экономизма, но поиск, изобретение путей его преодоления. Для этого и потребовалось постижение сущности экономики, открытие законов ее развития. А потому называть такие «экономические» интересы материальными, чтобы увековечить их, равносильно тому, чтобы отождествлять механицизм с материализмом. Экономизм загораживает бытие и развитие, как это делает и механицизм. Нужно различать и противопоставлять экономику как часть общества, сторону общественной жизни, и экономизм, как часть, стремящуюся поглотить все общество, поглотить, подмять под себя все общественные явления.

Для развенчания и преодоления экономизма его, как и механицизм, нужно противопоставлять не только философской картине мира, но и научной картине, репрезентирующей не философскую онтологию бытия в целом, но конкретную

${ }^{1}$ Маркс К. Капитал // Маркс К., Энгельс Ф. Соч. Изд-е 2. Т. 25. Ч. II. C. $386-387$. научную онтологию познаваемого объекта или сущего. Предметом философии, взятой в форме общетеоретического мировоззрения, является чистое всеобщее или всеобщее как таковое, которое есть цель и душа философии. Предметом же любой науки является частное, единичное, конкретный «кусок» мироздания. Действительность же есть единство всеобщего, особенного и единичного. Всеобщее в ней существует не иначе как через особенное и единичное, а единичное и особенное существует не иначе как единичное и особенное проявление всеобщего. Данное обстоятельство с разных сторон обнаруживают философия, утверждая диалектический взгляд на это соотношение (например, Гегель), и наука, демонстрируя динамику восхождения от классической науки к науке неклассической и, далее, к постнеклассической науке.

В механической картине мира, взятой вне этой динамики, считалось, что фундаментом мироздания являются атомы, неделимые корпускулы, из которых построены все тела - жидкие, твердые и газообразные, которые взаимодействуют между собой на основе принципе дальнодействия, путем мгновенной передачи сил, подчиняясь жесткой лапласовской детерминации; взаимодействуют в абсолютном пространстве с течением абсолютного времени. Такие системы называют простыми или малыми системами. Их свойства однозначно определяются элементами (атомами и т.п.), которые вне системы обладают теми же свойствами, что и в системе; значит, система не порождает системного качества, свидетельствующего о несводимости целого к сумме частей. Вещь, тело, корпускула суть нечто первичное к процессу как их силовому взаимодействию; пространство и время рассматриваются как внешние к системе, движение и взаимодействие не сказываются на характеристиках пространства и времени. На основе такой «онтологической схемы» рассматривали электродинамическую картину, хотя уже обнаруживалась неадекватность ее более сложным типам системной организации объектов. При их объяснении возникали «парадоксы», демонстрирующие потребность в ее пересмотре.

Пересмотр в физике оказался связанным с разработкой квантово-релятивистской физики. Обнаружился корпускулярно-волновой дуализм микрообъектов. Квантово-механическое описание многочастичных объектов открыло кооперативный эффект: совместное действие 
частиц демонстрировало свойства, не присущие отдельно взятым частицам (сверхпроводимость, сверхтекучесть, когерентное электромагнитное излучение), прежнее представление о причинности потребовало дополнения вероятностной причинностью, в СТО Эйнштейна были элиминированы представления об абсолютности пространства и времени, появилась идея различения внутреннего и внешнего пространства физических систем. Еще большие изменения были связаны с биологией, где дали о себе знать системные качества целого, нередуцируемые к свойствам образующих его элементов, где утвердилась идея несводимости целого к простой, аддитивной сумме частей. Изменялись представления о причинности, возникли представления о цииклической причинности. Вещь стала пониматься как процессуальная система, которая самовоспроизводится в результате взаимодействия со средой на основе саморегуляции. Радикальному переосмыслению подверглись категории части и целого, их соотношение: вхождение частей в систему: их свойства определяются характером ее целостности. Если в рамках механистической картины мир уподобляли часам, механическому устройству, то в неклассической науке при освоении сложных систем в технике и с развитием кибернетики в середине XX века мир стали уподоблять организму, рассматривали его как процесс, исключающий «мертвое равновесие» и «предопределенность вперед установленной гармонией» в духе Г. Лейбница ${ }^{1}$. Мир объектов стал восприниматься на основе онтологии сложных саморегулирующихся систем².

Этот пересмотр онтологии системности объектов науки продолжился с появлением постнеклассической науки, будучи определяемым еще большей сложностью систем, которые характеризуются, во-первых, уже не только как саморегулирующиеся, но и как саморазвивающиеся, во-вторых, как «человекоразмерные» системы, поскольку они включают в свой состав людей, субъектов, преследующих свои собственные цели, для реализации которых они подбирают те или иные средства их достижения. Общим для классики и неклассики является то, что ни классическая, ни неклассическая рациональность не выводят нас в область человеческой

\footnotetext{
${ }^{1}$ Винер Н.Я — математик. М., 1964. С. 314.

${ }^{2}$ Стёпин В.С. Цивилизация и культура. СПб., 2011. С. 172.
}

деятельности, которая имеет специальной целью переделку действительности, что отличает их от постнеклассической науки, изучающей сверхсложные системы с участием человека как целеполагающего начала в таких системах. Только здесь можно вести речь о предумышленном изменении онтологии объекта человеком взамен «созерцающего сознания», ибо "само человеческое действие не является чем-то внешним», а «включается в систему, видоизменяя каждый раз поле ее возможных состояний» ${ }^{3}$.

Обнаруживаются противоположные типы редукционизма. С одной стороны, неправомерен традиционный редукционизм, когда сложные системы сводятся к простым, механическим, с другой стороны, неоправданно рассматривать простые системы как всегда включенные в сложные, по идеалам и образцам сложных систем, с отрицанием их самостоятельного существования.

Переход науки на ступень постнеклассики предполагает идеи и представления об эволюции основных сфер Универсума - неживой природы, живой природы и общества. Эти идеи «универсального эволюционизма» «составляют концептуальное ядро современной научной картины мира», начинающей функционировать «в качестве исследовательской программы», получая свою конкретизацию, например, в виде синергетики 4 . Они явно далеко выходят за пределы и механицизма, и экономизма. Ведь нужно учитывать, что свойства экономики как подсистемы общества обусловлены обществом, состоящим не только из экономики. «При изучении «человекоразмерных» объектов поиск истины оказывается связанным с определением стратегии и возможных направлений преобразования такого объекта, что непосредственно затрагивает гуманистические ценности», “объективно истинное объяснение и описание применительно к «человекоразмерным» объектам не только допускает, но и предполагает включение аксиологических факторов в состав объясняющих положений», как и решение «проблем этического характера, определяя границы возможного (и необходимо-

\footnotetext{
${ }^{3}$ Стёпин В.С. Классика, неклассика, постнеклассика: критерии различения // Постнеклассика: философия, наука, культура: Коллективная монография / отв. ред. Л.П. Киященко и В. С. Стёпин. СПб., 2009. С. 283.

${ }^{4}$ Стёпин В.С. Цивилизация и культура. СПб., 2011. С. 181, 166, 183.
} 


\section{Философия и культура 1(73) • 2014}

го! - М.П.) вмешательства»'. Нормы и идеалы постнеклассической науки позволяют преодолеть изображение частного, экономического процесса, ставшего универсальным в духе экономизма, открыть возможность представления экономики как частного проявления всеобщего развития бытия и общества.

Уж если материя, еще лишенная разума, не обретшая его, все же сумела обеспечить приоритет восхождения над нисхождением, преодолев механицизм, на который ее обрекали люди, сторонники механицизма, то для разумной материи, представленной противниками экономизма, обеспечение такого приоритета следует признать идеалом и нормой. «Тюремное заключение» человечества не может продолжаться вечно: неправомерно отождествлять «экономизм» (как и «механицизм») с «материализмом». Преодолевая это «пещерное бы- тие», с одной стороны, предстоит освободиться от чрезмерной «подручности», «средственности» человека (М. Хайдеггер), с другой стороны, нужно утверждать «субъектность личности, чтобы сам индивидуально-ответственный способ существования в мире возвысить до исторически значимой величины»².

Данная проблема сегодня превратилась в острую и актуальную проблему отчуждения от социальности, в результате которого не только постсоветская Россия, но и все человечество, вся земная цивилизация явно вступила на гибельный путь самоуничтожения ${ }^{3}$. Экономизм и является основанием отчуждения от социальности. Его преодоление будет способствовать преодолению отчуждения от социальной реальности, как преодоление механицизма способствовало преодолению отчуждения от материальной реальности вообще.

\section{Список литературъ:}

1. Алексеев П.В., Панин А. В. Философия. М., 2014.

2. Бабочкин П.И., Камалдинова Э.Ш. Социальная и культурная реальность современного российского общества // Философия и культура. 2012. № 8. С. 41-45.

3. Бердяев Н.А. Человек и машина. Проблема социологии и метафизики техники // Вопросы философии. 1989. № 2.

4. Борисенков А.А. Парадигмальное знание в политической науке как фактор её развития // Философия и культура. 2011. № 10. С. 8-15.

5. Винер Н.Я - математик. М., 1964.

6. Вирин М. М. Вклад русской школы исследований эволюции и прогнозов развития человечества в формирование концепции информационного общества // Философия и культура. 2012. № 3 . C. $36-46$.

7. Гольбах П.А. Избранные произведения: В 2-х т. Т. 1. М., 1963.

8. Гуревич П. С. Феномен стабильного общества // Философия и культура. 2011. № 8. С. 61-74.

9. Гусейнов А.А. Что говорил Кант, или Почему невозможна ложь во благо? // Логос. 2008. № 5.

10. Дубровский Д. И. Проблема добродетельного обмана. Кант и современность // Вопросы философии. 2010. № 1 .

11. Зима В.Н. Проблема онтологического статуса времени в философии науки: анализ основных трудностей // Философия и культура. 2013. № 1. С. 50-59. (DOI: 10.7256/1999-2793.2013.01.4).

12. Иглтон Терри. Почему Маркс был прав. М., 2013.

13. Козин Н. Г. Есть ли будущее у России? Критика исторического опыта современности. М., 2008.

14. Копнин П. В. Гносеологические и логические основы науки. М., 1974.

15. Кузнецов В.Н. Проблема значения понятий «материалисты» и «материализм» в новоевропейской философии XVII-XVIII веков» // Историко-философский альманах: Вып. 2. М., 2007.

16. Лейбниц Г. В. Сочинения: В 4-х т. Т. 1. М., 1982.

17. Максимов В.Е. Самоистребление. М., 1995.

1 Стёпин В.С. Классика, неклассика, постнеклассика: критерии различения. С. 285-286; Так же: Копнин П. В. Гносеологические и логические основы науки. M., 1974. C. 43-46.

\footnotetext{
${ }^{2}$ Гусейнов А. А. Что говорил Кант, или Почему невозможна ложь во благо? // Логос. 2008. № 5. С. 120.

${ }^{3}$ Дубровский Д.И. Проблема добродетельного обмана. Кант и современность // Вопросы философии. 2010. № 1. С. 31.
} 
18. Маркс К. Экономическо-философские рукописи 1844 г. // Маркс К., Энгельс Ф. Из ранних работ. М., 1956.

19. Моркина Ю.С. Б. Латур. Попытка нового взгляда на людей и вещи в исследовании науки // Философия и культура. 2011. № 6. С. 121-131.

20. Моррис Генри. Сотворение мира: научный подход. Сан-Диего, Калифорния, 1981.

21. Петушкова Е. В. Механицизм // Новейший философский словарь. Минск, 1998.

22. Платонов С. После коммунизма: Кн., не предназначенная для печати. 2-ое изд. Второе пришествие: Беседы. М., 1991.

23. Попов Е.А. Междисциплинарный опыт гуманитарного знания и современной социологической науки // Политика и общество. 2013. № 4. C. 441-447. (DOI: 10.7256/1812-8696.2013.04.8).

24. Потемкин А. Механицизм // Философская энциклопедия: В 5-и т. Т. 3. М., 1964.

25. Прохоров М. М. Несколько соображений о марксистской философии и современности // Вестник Российского философского общества. 2010. № 4 (56). С. 87-91.

26. Саввина О.В. Исследования в области этики научного сообщества и тенденции её развития // Философия и культура. 2011. № 5. С. 148-154.

27. Семенов В. С. Судьбы философии в современной России. М., 2011.

28. Урсул А.Д., Урсул Т.А. Глобальные исследования и становление ноосферы через устойчивое развитие // Политика и общество. 2012. № 4. С. 114-125.

\section{References (transliteration):}

1. Alekseev P.V., Panin A. V. Filosofiya. M., 2014.

2. Babochkin P.I., Kamaldinova E. Sh. Sotsial'naya i kul'turnaya real'nost» sovremennogo rossiiskogo obshchestva // Filosofiya i kul'tura. 2012. № 8. C. 41-45.

3. Berdyaev N. A. Chelovek i mashina. Problema sotsiologii i metafiziki tekhniki // Voprosy filosofii. 1989. № 2 .

4. Borisenkov A.A. Paradigmal'noe znanie v politicheskoi nauke kak faktor ee razvitiya // Filosofiya i kul'tura. 2011. № 10. C. 8-15.

5. Viner N. Ya - matematik. M., 1964.

6. Virin M. M. Vklad russkoi shkoly issledovanii evolyutsii i prognozov razvitiya chelovechestva $\mathrm{v}$ formirovanie kontseptsii informatsionnogo obshchestva // Filosofiya i kul'tura. 2012. № 3. C. 36-46.

7. Gol'bakh P. A. Izbrannye proizvedeniya: V 2-h t. T. 1. M., 1963.

8. Gurevich P. S. Fenomen stabil'nogo obshchestva // Filosofiya i kul’tura. 2011. № 8. C. 61-74.

9. Guseinov A. A. Chto govoril Kant, ili Pochemu nevozmozhna lozh» vo blago? // Logos. 2008. № 5.

10. Dubrovskii D. I. Problema dobrodetel'nogo obmana. Kant i sovremennost» // Voprosy filosofii. 2010. № 1.

11. Zima V.N. Problema ontologicheskogo statusa vremeni v filosofii nauki: analiz osnovnykh trudnostei // Filosofiya i kul'tura. 2013. № 1. C. 50-59. (DOI: 10.7256/1999-2793.2013.01.4).

12. Iglton Terri. Pochemu Marks byl prav. M., 2013.

13. Kozin N. G. Est» li budushchee u Rossii? Kritika istoricheskogo opyta sovremennosti. M., 2008.

14. Kopnin P.V. Gnoseologicheskie i logicheskie osnovy nauki. M., 1974.

15. Kuznetsov V. N. Problema znacheniya ponyatii «materialisty» $\mathrm{i}$ «materializm» v novoevropeiskoi filosofii XVII-XVIII vekov» // Istoriko-filosofskii al'manakh. Vyp. 2. M., 2007.

16. Leibnits G. V. Sochineniya: V 4-h t. T. 1. M., 1982.

17. Maksimov V.E. Samoistreblenie. M., 1995.

18. Marks K. Ekonomichesko-filosofskie rukopisi 1844 g. // Marks K., Engel's F. Iz rannikh rabot. M., 1956.

19. Morkina Yu.S. B. Latur. Popytka novogo vzglyada na lyudei i veshchi v issledovanii nauki // Filosofiya i kul'tura. 2011. № 6. C. 121-131.

20. Morris Genri. Sotvorenie mira: nauchnyi podkhod. San-Diego, Kaliforniya, 1981.

21. Petushkova E.V. Mekhanitsizm // Noveishii filosofskii slovar». Minsk, 1998.

22. Platonov S. Posle kommunizma: Kn., ne prednaznachennaya dlya pechati. 2-oe izd. Vtoroe prishestvie: Besedy. M., 1991.

23. Popov E. A. Mezhdistsiplinarnyi opyt gumanitarnogo znaniya i sovremennoi sotsiologicheskoi nauki // Politika i obshchestvo. 2013. № 4. C. 441-447. (DOI: 10.7256/1812-8696.2013.04.8). 


\section{Философия и культура 1(73) • 2014}

24. Potemkin A. Mekhanitsizm // Filosofskaya entsiklopediya: V 5-i t. T. 3. M., 1964.

25. Prokhorov M. M. Neskol'ko soobrazhenii o marksistskoi filosofii i sovremennosti // Vestnik Rossiiskogo filosofskogo obshchestva. 2010. № 4 (56). S. 87-91.

26. Savvina O. V. Issledovaniya v oblasti etiki nauchnogo soobshchestva i tendentsii ee razvitiya // Filosofiya i kul'tura. 2011. № 5. C. 148-154.

27. Semenov V. S. Sud'by filosofii v sovremennoi Rossii. M., 2011.

28. Ursul A.D., Ursul T.A. Global'nye issledovaniya i stanovlenie noosfery cherez ustoichivoe razvitie // Politika i obshchestvo. 2012. № 4. C. 114-125. 